Скороходова Т.Г.

\title{
Духовные искания индийской интеллигенции и универсализация индуизма
}

Аннотация: Процесс универсализации индуизма описан в статье как новая интерпретация индуистской традиции интеллектуалами Индийского Возрождения ХІХначала $X X$ вв. Автор рассматривает трактовки индуизма, предложенные Раммоханом Раем и основанным им обществом Брахмо Самадж, в Прартхана Самадже, Свами Дайянандой и его Аръя Самаджем, а также неоиндуистскими мыслителями Бонкимчондро Чоттопаддхаем, Свами Вивеканандой и Балом Гангадхаром Тилаком, как различные варианты ответа на ключевой вопрос духовно-интеллектуального поиска - о реальном содержании индуизма. На основе феноменологического подхода данный процесс представлен как диалог индуизма и других религий (прежде всего христианства и ислама) и создание особого образа индуизма в сознании индийского интеллектуала. Варианты интерпретаций лежат в основе религиозных движений - реформистских и неоиндуистских. Автор показывает, что в Бенгалии, Махараштре и Панджабе интеллектуальная универсализация индуизма позволила обосновать мировой статус этой религии. Универсализация представлена в двух вариантах. Первый - негативная универсализация от острой критики религиозных форм к обоснованию высокого монотеизма и гуманистической этики. Второй - позитивная универсализация, основанная на принятии всех форм богослужения как различных путей к Божественному Абсолюту. Индуизм был символически описан интеллектуалами как универсальная мировая религия, хранящая высочайшие истины для всего человечества.

Ключевъе слова: Мировая религия, индийская духовная культура, индуизм, Индийское Возрождение, универсализация веры, реформация, реформаторские общества, неоиндуизм, универсальные духовные смыслы, образ индуизма.

Review: The process of Hinduism's universalization is depicted in the article as re-interpretation of Hindu tradition by intellectuals of the Indian Renaissance XIX-early XXth century. The author considers the interpretations by Rammohun Roy and his Brahmo Samaj, Prarthana Samaj, Swami Dayananda and his Arya Samaj, and also by Neo-Hindu thinkers Bankimchandra Chattopadhyay, Swami Vivekananda and Bal Gangadhar Tilak, as different variants of answers to key questions of spiritual and intellectual searches for real essence of Hinduism. Based on the phenomenological approach, the process is represented as the dialogue between Hinduism and other religious -first of all, Christianity and Islam - and creation of a concrete image of Hinduism as universal religion in Indian intellectuals' minds. The variants of the interpretations underlie the religious movements - reformist and neo-Hinduist. The author suggests that in Bengal, Maharashtra and Punjab intellectual universalization of Hinduism had helped to ground the world status of the religion. The universalization had two variants. The first one was a negative universalization from sharp critics of religious forms to grounding high monotheism and humanist ethics. The second one was a positive universalization based on accepting of all worship forms as different paths to Divine Absolute. Hinduism was symbolically depicted by intellectuals as a universal world religion, the repository of highest truth for all humanity.

Keywords: World religion, Indian spiritual culture, Hinduism, the Indian Renaissance, universalization of creed, reformation, reformist societies, neo-Hinduism, universal spiritual meanings, image of Hinduism.

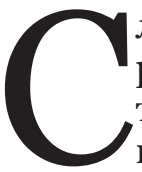

ложнейшую и многослойную систему религий Индостанского субконтинента, носящую с конца XVIII в. обобщённое европогенное имя «индуизм» [Cм.: 8], нередко называют национальной религией Индии, чтобы подчеркнуть её связь с цивилизацией и её интегрирующую роль как духовной традиции. Вовлекая в свою орбиту многочисленные региональные и местные доарийские верования и культы, исторически религия дхармы не была склонна к прозелитизму и не стремилась распространять духовные истины за пределы цивилизационного ареала. Она давала пристанище и своеобраз- 
ную защиту представителям иных религий (парсов, иудеев, христиан, мусульман), в каком бы качестве они ни приходили - мирных переселенцев или завоевателей. Она могла вполне целенаправленно вытеснять внутренних конкурентов, как делала это с буддистами, но допуская при этом сосуществование внутри себя ортодоксальных и неортодоксальных пластов и течений $[16,1-3]$. Однако притязания на всеобщность/универсальность вероучения в традиционном индуизме, в отличие от других мировых религий, практически отсутствовали. Этому способствовали, с одной стороны, элитарность представлений о высших истинах и высшем знании - их носителями выступали главным образом высшие варны, а с другой - общая социокультурная замкнутость традиционного общества Индии, не испытывавшего в общем и целом интереса к Другому, будь то иная культура, народ, цивилизация или человек [Cм.: $1 ; 5 ; 14]$.

Является ли индуизм во всём его многообразии универсальной религией в том смысле, что он, подобно другим религиям, обращается ко всем людям? А. Дж. Тойнби даёт положительный ответ на этот вопрос, когда называет индуизм в ряду высших религий ХХ века вместе с христианством, исламом и буддизмом махаяны. Признаками высших религий Тойнби называет взгляд на Бога как Господа человеческого, которого носят в сердце, а также освобождение человека от вечного рабства внутри собственного «Я» и компоненты спасения и преодоления страдания [7, 524]. Однако если учесть, что универсальность как всеобщность подразумевает обращение высшей религии к каждому человеку независимо от любых его характеристик и возможность принятия этого вероисповедания, то - несмотря на сходство смыслов, отмеченное Тойнби, индуизм в этот ряд не вписывается.

Что тогда понимать под универсальностью индуизма, если прозелитизм в нём отсутствует, и индуистом можно только родиться, унаследовав место в варново-джатной системе и исполняя дхарму? В традиционном индуизме есть все отмеченные Тойнби признаки, однако обнаруживаются они в разных его слоях - в рафинированной теологии веданты, в эмоциональном мире неортодоксальных течений бхакти, в идее мукти/мокши, в практиках «народного индуизма». Все вместе эти признаки появляются только в интеллектуальных построениях эпохи Индийского Ренессанса XIX - 1 трети XX вв. Соответственно, процесс универсализации национальной религиозной традиции начинается с периода вовлечения Индии в модернизационные процессы, вскоре после установления британского колониального правления. Оно способствовало экономической, социальной и культурной трансформации сначала в Бенгалии, а затем, по мере дальнейшего завоевания Индии, на всём субконтиненте. Главными движущими центрами модернизационных процессов в культуре стали колониальные города-порты, своеобразные «окна в Европу» - Калькутта, Бомбей, Мадрас. Именно здесь, вдали от традиционных центров паломничества, учёности и ортодоксии, возникают духовные движения, в которых воплощены результаты духовного поиска истины в индуизме.

Под универсализацией индуизма я понимаю в первую очередь интеллектуальный процесс интерпретации духовной традиции индийской цивилизации (санатана дхармы) в контексте современных процессов диалога восточных и западных культур и религий. Цель этой интерпретации - обоснование смыслов и истин индуизма ради его защиты в ответ на критику - в первую очередь со стороны христианских миссионеров, хотя нелицеприятная критика индийских реформаторов в адрес индуизма общеизвестна. Эта защита индуизма, есть оправдание - если следовать трактовке слова «оправдание» в библейском контексте, данной Е. Б. Рашковским в работе о Вл. Соловьёве [2, 35-37], - как открытие правды о собственной религиозной традиции, как упорядочение её сфер и уравнивание с другими мировыми религиями.

Универсализация индуизма в масштабах Индии стала делом относительно небольшого слоя городских интеллектуальных элит. Являясь выходцами преимущественно из высоких каст, они получали европейское образование (наряду с традиционным или же без него), которое развивало критическое мышление и открывало возможность познания других культур. Пребывание в городском пространстве пересечения и взаимодействия индийской и западной культур превращали интеллигента в «паломника в страну Запада» (перефразируя Г. Гессе), который перемещался в сознании или реальности в пространство иных культур и постигал их смыслы. В отличие от носителей традиционной учёности (learned men), этих образованных людей (educated men) вполне можно отнести по статусу и роду занятий к интеллигенции, хотя многие из них имели 
отношение к развивающемуся индийскому бизнесу и управлению. Воспитание в индуистской традиции делало индийского интеллектуала носителем определённого религиозного опыта, связанного с практикой конкретного культа (вишнуитского или шиваитского толка), а западное образование могло сделать из правоверного индуиста строгого критика родной традиции, искателя истины - не только о Боге, но и о самом индуизме.

Генезис духовных поисков интеллектуалов связан с развёрнутой после завоевания активной проповедью христианских миссионеров, которые вместе с просветительской и научной работой по изучению языков и культуры местного населения развернули идеологическое наступление против индуистских верований, культов и практик в традициях «обличительного» богословия. Примером такого наступления была вышедшая в середине XIX века книга шотландского пресвитерианского миссионера, священника «Индия и индийские миссии», полная не только критики индуизма как «язычества», но и самой индийской культуры [12]. Особенно интенсивно прозелитистская и идеологическая работа велась в городах; хотя успех её был скромен, сопоставление христианства и индуизма было не в пользу последнего, тем более что фоном сравнения двух религиозных традиций был разительный контраст между пришедшей модернизирующейся европейской цивилизацией и традиционной социокультурной системой Индии.

Универсализация индуизма как духовный и социальный процесс XIX- 1 половины XX в. один из аспектов Индийского Ренессанса, наряду с аспектами социального, культурного и политико-правового творчества элит разных регионов субконтинента, воплотивший поиски пути в современность для своего общества и проектирование развития страны в новых исторических условиях. Соположенность индуизма и христианства в контексте различий между цивилизациями, уровнем их развития, а также между культурами вызвали интенсивные размышления интеллектуалов о сути индийской духовной традиции - о смысле и содержании. Ключевой вопрос, вокруг которого строился духовно-интеллектуальный поиск вопрос о том, что есть индуизм в реальности.

На этот вопрос уже было минимум три общих варианта ответа: брахманский - изнутри традиции, обосновывающий истинность индуизма ссылками на авторитет Вед, миссионерский - извне, относящий индуизм к язы- честву, а также ориенталистский, связанный с научными исследованиями религии, культуры и истории Индии, которые предпринимались европейскими учёными. Последний вариант сочетал в себе попытки объективно оценить эволюцию религиозных верований Индостана и одновременно учесть брахманские интерпретации дхармы и культуры.

Индийские интеллектуалы изначально критически воспринимают все эти варианты, и ни один не устраивает их полностью. Брахманский, несмотря на однозначную позитивность всех провозглашаемых истин, ортодоксален и закрыт для критики и диалога. Миссионерский «обличительный» ответ строится на отрицании самой возможности присутствия в индуизме высоких истин. Оба варианта ответа в притязании на исключительность и превосходство в отношении других религий, что неприемлемо для интеллектуала, прошедшего школу европейского рационально-научного мышления. Ответ ориенталистов относительно нейтрален и рационален, однако ему не хватает взгляда изнутри традиции, которой как раз и обладает интеллигент-индуист. И потому он берёт на себя задачу дать собственный ответ на вопрос о сути индуизма, осознанно или интуитивно руководствуясь желанием его оправдать - открыть о нём правду, его подлинное содержание.

Весь комплекс ответов интеллектуалов на вопрос о сути и содержании индуизма можно разделить на две группы по используемому подходу к соотношению должного и сущего в индуизме. Первая группа трактовок индуизма происходит из чёткого разграничения сущего - т. е. наличного состояния индуистских культовых практик и поведения верующих, и должного - представления о том, что является подлинным вероучением и истиной в индуизме, и о том, каким ценностям и нормам должен следовать индуист. Этот подход используют религиозные реформаторы, для которых действительное состояние индуизма представляется минимум как духовный, моральный и социальный упадок, требующий усилий по его преодолению и изменений в сторону восстановления должного идеала, ценностей и норм. Этот подход исторически первичен в Индийском Ренессансе.

Вторая группа трактовок исходит из принятия сущего в индуизме как многогранной и полной смысла целостности, всего многообразия верований и практик которые в конечном счёте обоснованы и оправданы 
общей истиной, скрытой за внешними различиями. Здесь имеет место своеобразное возвышение сущего до должного - представления о высшем смысле и истине, которое к тому же весьма сходно с представлениями о должном в трактовках первой группы. Впервые такое возвышение сущего до должного появляется у традиционных вероучителей, которые проповедуют о достоинствах родной религии и которым внимают индийские интеллигенты. Из их среды появляются ученики, которые впоследствии становятся основателями неоиндуистских движений. Исторически они связаны с ростом патриотических настроений в среде интеллектуальных элит и развитием культурного и политического национализма в последней трети XIX в. в индийских регионах.

Процесс универсализации индуизма начинается с поиска и открытия через сравнение универсальных духовных смыслов в родной религии и продолжается в выстраивании диалога с другими религиями (христианство, ислам, буддизм и др.) и обосновании достоинств индуизма как одной из мировых религий. Феноменологически процесс представляется как выстраивание в сознании интеллектуала диалога индуизма с другими религиями (чаще всего это триалог индуизма - ислама - христианства) и поиск смысловых точек соприкосновения и сходства, а затем и сопоставление культов внутри индуизма друг с другом и с философскими построениями его даршан. На основе диалога и критики создаётся определённый образ индуизма, в котором на первом плане - независимо от содержания - оказывается универсальное начало, хотя и в разных вариациях. В свою очередь на основе этого образа появляется духовное движение, проецирующее его не только в религиозную, но и в социальную, культурную и политическую сферы жизни, благодаря чему происходят заметные трансформации в обществе. Кроме того, универсализация индуизма принимает формы религиозных течений, постулирующих возможность обрести спасение с помощью индуистских садхан для всех - независимо от изначальной религиозной принадлежности. Этот вид универсализации известен под названием неоиндуизма.

Использование подхода, разграничивающего сущее и должное в индуизме, имело результатом религиозно-реформаторскую универсализацию, которая происходит в Бенгалии, Махараштре и Панджабе. Интеллекту- алы Калькутты и Бомбея были первыми, кто критически отнёсся к актуальному состоянию практик и сознания единоверцев.

«Отец Индийского Ренессанса», философ и реформатор Раммохан Рай (1772-1833) впервые задался вопросом о сути индуизма и, находясь в пространстве соприкосновения трёх культурных традиций - санскритской, мусульманской и европейской - выстроил в своём сознании триалог индуизма, ислама и христианства. Влияние исламского монотеизма, испытанное в ранней юности как мощная альтернатива его детскому опыту вишнуитского бхакти, а также не менее мощное влияние адвайта-веданты обусловили предпонимание сути индуизма: «Вера в одного Всемогущего Бога является фундаментальным принципом любой религии» $[17, \mathrm{IV}, 957]$. Это представление о должном лежит в основе образа индуизма, построенного Раммоханом. «Истинная система религии ведёт своих приверженцев к знанию и любви к Богу, к дружественному отношению к ближним, воздействуя на их сердца одновременно со смирением и милосердием, в сочетании с независимостью ума и чистой искренностью» $[17, \mathrm{I}, 46]$, - этот универсальный этический монотеизм Раммохан Рай ищет в индуизме и находит в веданте, где есть представление об универсальном и едином, благом и вездесущем Брахмане - подлинной первопричине мира. «Доктрины единства Бога есть настоящий индуизм, - заявляет Раммохан, - ...так эта религия понималась нашими предками и ...как таковая, она известна в настоящее время многим учёным брахманам» $[17, \mathrm{I}, 90]$. Современное состояние индуизма Раммохан воспринимает как глубокий духовный и социальный упадок, который явился следствием забвения высокого и чистого вероучения древности, чему на протяжении веков способствовали брахманы во имя «своего удобства, благополучия и укрепления власти» $[17, \mathrm{I}, 66]$. Этот упадок имеет духовное проявление в обрядоверии, ритуализме, поклонении изображениям многочисленных богов, церемониях, праздниках, предрассудках и суевериях «народного индуизма», и его социальным проявлением Раммохан считает бесчеловечные обычаи (сати, инфантицид) правила кастовой системы и общее нравственное саморазрушение единоверцев. Выход из этого упадка реформатор видел в возвращении к духовному и этическому содержанию индуизма, - в том виде, как он явлено в Ведах, отождествляемых им с Упанишадами. 
Раммохан Рай создал идеальный образ индуизма, в котором присутствуют главные универсальные мотивы родства с другими религиями и который столь же рафинирован и элитарен, как и философия веданты в соотнесении с народным индуизмом. Это монотеистическая вера, в которой поклонение Богу осуществляется через размышление о нём, преданность и этически благие действия, не связанные с исполнением ритуала. Этика индуизма по Раммохану - это исполнение долга добродетельной жизни, человеколюбие, милосердие, сострадание, воздержание от дурных поступков, обуздание чувств [17, I, 46, 53]. Этот образ индуизма, понятный в первую очередь просвещённым элитам, Раммохан Рай положил в основу общества «Брахмо Самадж» («Общество поклонения Брахману», 1828), и тем начал историю брахмоистского движения. Брахмоисты дополняют и развивают этот должный образ индуизма (Д. Тагор, К. Сен и др.), усиливают его социальное содержание, чтобы содействовать просвещению и реформам в обществе. Брахмоистское движение стало авангардом социального реформаторства и культурного развития не только в масштабах Бенгалии, но и Индии, поскольку со второй половины XIX в. филиалы Брахмо Самаджа возникают во многих городах Индии, а сотрудничество устанавливается с другими региональными обществами реформаторского типа.

В Махараштре интеллектуалы нового поколения - выходцы из высоких каст - стали основателями реформаторских обществ. Первое тайное общество «Гупта Сабха» было реакцией на активную прозелитистскую деятельность христианских миссионеров [4, 58], другое - «Парамахамса Сабха» - ставило в Бомбее задачей обсуждение реформы индуизма и разрушения кастовой системы [18, II, 411]; в реальной практике его члены нарушали пищевые запреты и правила общения с иноверцами. А в 1867 г. был основан «Прартхана Самадж» («Молитвенное общество»), объединивший верующих в Единого Бога и ставивший целью содействие преодолению социальных пороков, а именно 1) открытое обличение кастовой системы; 2) введение вторичного замужества вдов; 3) поощрение женского образования и 4) отмену детских браков [18, II, 412]. У истоков этого общества, тесно сотрудничавшего с Брахмо Самаджем, но не присоединявшегося к нему, стояла группа неортодоксальных брахманов-читпаван, о ко- торых Д. Копф замечает: «Они были не просто членами высочайшей касты в общине, но и профессионалами с западным образованием, весьма успешными как ... судьи, врачи, журналы, профессора и гражданские служащие» $[15,320]$ - врач Атмарам Пандуранг, историк Рамкришна Гопал Бхандаркар, юрист и экономист Махадев Говинд Ранаде, политик и реформатор Нарайян Ганеш Чандаваркар и другие.

Члены Прартхана Самаджа считали себя настоящими индуистами, но взамен почитания образов богов, аватар и священных книг приняли духовное служение Богу, и потому заменили прежние формы богослужения еженедельными молитвенными собраниями по образцу прихода. В качестве молитв и гимнов использовались произведения средневековых поэтов варкари - местной традиции бхакти (XIII-XVII вв.) Тукарама и Намдева. Членам общества особенно импонировали проповедь равенства и братства всех людей перед Богом. Деятельность Прартхана Самаджа, следовавшего в религиозной сфере монотеистическому пониманию сути индуизма, отрицавшего идолопоклонство и осуществлявшего приходское богослужение, показывает, как этическое единобожие духовно мотивирует социально-просветительскую деятельность в области женской эмансипации, просвещения и поддержку социальных низов.

Общество «Арья Самадж» (букв. «Общество благородных»), основанное в 1875 г. в Бомбее Свами Дайянандой и в 1977 перенесённое в Лахор (Панджаб) и быстро покрывшее сетью своих отделений Северную, Центральную и отчасти Южную Индию, во многом было сходно с реформаторскими обществами Бенгалии и Махараштры, однако отличалось более этнофильским характером. Его особенности связаны с образом индуизма, созданным Свами Дайянандой в ходе ответа на вопрос о сути этой религии.

В известной степени Дайянанда - исключение из общих правил становления как интеллектуала-реформатора, так и интеллектуала-неоиндуиста. Сын гуджаратского ортодоксального брахмана-знатока Вед, получивший только традиционное санскритское образование, он усомнился в индуизме в результате душевного потрясения в ночь Шиваратри, когда увидел, что мыши поедают прасад (освященная пища, подносимая богам) для Шивы и бог-изваяние не протестует. «Мысли одна за другой теснились в моей голове, и вопросы 
один за другим поднимались в моем смущенном сознании. Возможно ли, - спрашивал я себя, - что это подобие человека, идол Личного Бога, которого я видел сидящим на буйволе предо мною, и который, согласно всем религиозным текстам, ходит, ест, спит и пьет, который может держать трезубец в своей руке, бить в домору (вид барабана) и проклинать людей - возможно ли, что он может быть Махадевой, - великим Божеством, тем же самым, к которому взывают как к Владыке Кайласы, верховному существу и Божественному герою всех сказаний, которые мы читаем в пуранах?» [Цит. по: 13, 34]. Духовный кризис привёл к уходу из дома, скитаниям по Индии в поисках истины и учителя, который ответит на вопросы об индусском идолопоклонстве, обрядоверии и кастах. Дайянанда не получил английского образования и в этом смысле не был «паломником в страну Запада», но был знаком с Библией и Кораном в переводе, и был знатоком священных книг, эпоса, шести ортодоксальных даршан (философских школ) и шастр (законодательные сборники). Особой книгой, прочитанной им, была Индия - традиционная, полная суеверий, невежества, унижений и идолопоклонства. Будущий реформатор, в отличие от реформаторов Бенгалии и Махараштры, был учеником традиционного гуру Свами Вирджананды Сарасвати, который ценил во всём комплексе ведийских текстов только самхиты (собрания гимнов) и комментарии, а остальные тексты, включая пураны, считал поздними фальсификациями. Он убедил ученика в том, что современный индуизм - это искажение великого наследия Вед и взял с него слово, что он посвятит жизнь очищению засорённой пуранической веры, восстановлению правильных религиозных методов добуддийских времён и распространению истины [3, 89].

В учении Свами Дайянанды образ индуизма создан на основе идей Вирджананды и убеждённости в превосходстве этого понимания - а диалог с христианством и исламом, a также с европейскими ориенталистами, ведётся уже post factum, ради подтверждения своей правоты. Несмотря на целый ряд параллелей с идеями других реформаторов, Свами Дайянанда отличается от них безоговорочным признанием истинности и непогрешимости Вед - единственного источника откровения, знания и всех открытий науки. «Моя концепция Бога и всех других объектов во вселенной основана на учениях Вед и дру- гих истинных шастрах, и находится в согласии с верой всех святых от Брахмы до Джаймини», - заявляет он [Цит. по: 13, 35]. Веды - слово единого Бога, который трактуется сообразно традиции как cam-чum-ананада и Творец вселенной. Проявление веры в него, по Дайянанде, - молитва и праведное поведение, соответственно идолопоклонство, ритуалы, вишнуизм, шиваизм, мифология, праздники, обычаи, паломничества, социальные установления кастовой системы и роль брахманства абсолютно противоречат истинам Вед и должны быть преодолены. Содержание этого образа - ревайвалистское, т. к. Дайянанада предлагает возродить древнюю веру ариев - благородных жителей арийского мира, тождественного всему человечеству. Этот ведийский универсализм не мешает Дайянанде называть ложными и индийские, и другие мировые религии, т. к. в них нет аръядхармы, - и призывать к возвращению в индуизм через церемонию шуддxu - очищение. Выступление за те же социальные реформы, за которые борются другие самаджи и реформаторы, а также за развитие науки и сварадж ставят Арья Самадж в один ряд с ними, однако стремление «нести добро в мир через усовершенствование условий существования человечества» арьясамаджисты реализовали, исходя из глубокого убеждения в знании единственного правильного способа - и потому способствовали росту ревайвализма, индусского национализмаи нетерпимости к иноверцам.

Думается, объяснение этих различий между реформаторами и самаджами не в последнюю очередь находится в религиозном происхождении и опыте их реформаторов-основателей. Несмотря на то что все трактовали индуизм как монотеистическую религию, отпечаток на образ и манеру действий самих реформаторов и их сторонников накладывало раннее воспитание в традиции вишнуизма - как у многих реформаторов Бенгалии и Махараштры, или же в традиции шиваизма. Влияние неортодоксальных движений бхакти - чайтанитов в Бенгалии, варкари в Махараштре - способствовало формированию диалогического образа мышления, корректные методы действий и - отсутствие коммуналистских тенденций, притязаний на истинность в последней инстанции и большую меру универсализма в теоретических исканиях и построениях. Дайянанда же, воспитанный в шиваитской традиции, более склонен к жёстким методам 
убеждения оппонентов, и в его организации присутствует «протокоммуналистский ведизм» (А. А. Ткачёва) $[6,81]$, больший напор в образе действий (движение шуддхи). Это характерно и для неоиндуистских вероучителей и деятелей. Так, выступления выходца из шиваитской семьи Свами Вивекананды отличаются особой энергией и силой убеждения, что, видимо, и позволяет ряду исследователей называть его проповедь и движение «агрессивным». Импульс от религиозно-реформаторских идей спроецировался в конце XIX в. в политическую сферу; политики-выходцы из брахмоистского движения и из Прартхана Самаджа - либералы, сторонники умеренных и конституционных методов политической деятельности; политики-арьясамаджисты больше склонны к религиозному национализму и экстремистским методам.

На основе подхода, принимающего индуизм в целом и возвышающего всё сущее многообразие культов и практики до должного - представления о его высоких духовных истинах, в последней четверти XIX - начале XX в. происходит неоиндуистская универсализация. Её центры практически те же - Бенгалия и Махараштра, хотя идеи интеллектуальных лидеров и инициированные ими движения выходят за пределы регионов. Неоиндуизм изначально формируется на основе интегрирующего представления о единстве индуизма как религии, объединяющей все виды верований и все формы поклонения с древности до современности. Шанкар Гхош справедливо отмечает, что неоиндуизм «был движением раскола, так сказать, протестантизмом против протестантов, протестом против англизированных индийцев, или “темнокожих англичан”, которые с первым приливом западного энтузиазма отбросили всё, что было славного в прошлом Индии» [Цит. по: 13, 76]. Индийские интеллектуалы пытаются соотнести реформаторские идеи и универсалистские представления с реальностью религиозной жизни страны в условиях пробуждения и роста патриотических настроений после Сипайского восстания 1857-1859 г. Родная религиозная традиция начинает восприниматься ими как мощная духовная опора и основание цивилизации - в том числе и членами реформаторских обществ. Так, уже в 1861 г. брахмоист Раджнарайон Бошу заявил о превосходстве индуистской религии и культуры над европейской, или христианской цивилизацией $[19,188]$.
Создателями интегрального неоиндуистского образа индуизма стали опять же бенгальцы - писатель Бонкимчондро Чоттопаддхай (1838-1894) и философ и общественный деятель Свами Вивекананда (Норендронатх Дотто, 1863-1902). Оба они прошли серьёзную школу европейской мысли и имели опыт духовных исканий, и оба оказались «у ног учителя» - традиционного проповедника Рамакришны Парамахамсы (1836-1886). При этом Бонкимчондро отошёл от своих либеральных воззрений и равнодушия к религиозным темам и стал основателем неоиндуистского течения в общественной мысли, а Свами Вивекананда в котором Рамакришна, видел продолжателя своей земной миссии, - основателем неоиндуизма как духовного движения. Универсализация индуизма также идёт с помощью диалога с другими религиями, унаследованного от предшественников-реформаторов, и вместе с тем - от Рамакришны, который в мистическом опыте постиг смысл других религий и признал их равную истинность как путей абсолютной духовной реальности.

Универсальный монотеизм лежит в основе образа индуизма у Бонкимчондро: «корень религии, в частности, индусской религии, - Единый Бог, Бог во всех вещах, следовательно, наша дхарма - в том, чтобы искать блага всех вещей» $[11,191]$. Однако в отличие от брахмоистов и Рамакришны, писатель заявляет, что во всех отношениях «индуизм... превосходит все другие религии» и «индусская религия - лучшая религия в мире» [11, 176], поскольку в ней, в отличие от ислама и христианства, объединяются все стадии богопознания - вера во всевышнего Творца, в личных богов и в воплощение Бога в человеке. Создавая образ индуизма, Бонкимчондро пользуется метафорой древа: «Ведический индуизм является корнем индуизма, но он не тождествен всему дереву. Дерево есть отдельная целостность сама по себе. Это дерево с перекрещивающимися ветвями, пышной листвой, цветами и плодами, и ничто из перечисленного не пребывает в корнях» [9, 63]. И потому в индуизме он различает два пласта - ведийский, в котором через множество богов почитают великого незримого Бога, и пуранический комплекс верований, связанных с религиозной историей, с появлением богов в человеческом облике. О безличном Боге, которого открыли ведические индусы, говорят философия и наука, однако он, по 
мысли Бонкимчондро, не может быть идеалом для человека, которому требуется «Бог с атрибутами», личный Бог в человеческом облике и религиозная история, изложенная в пуранах. Наилучшим примером почитания личного Бога для Бонкимчондро является культ Кришны, представленного как «Будда, Иисус Христос, Мухаммад и Рамачандра в одном лице». Индуизм в целом в его культовом и этическом измерении истолкован как религия совершенная, всеобъемлющая и «производящая-для-всех-счастье» [11, 164], религия любви, справедливости и личного самосовершенствования, а также как основа прогресса и творчества. Дхарма у Бонкимчондро тождественна садхане и понимается как универсальная для всех верующих.

Развивая идеи Рамакришны и свои собственные, Свами Вивекананда создаёт образ индуизма не только для индийцев, но и для всего мира, раскрывая высокий религиозный смысл реального индуизма для мировой общественности и одновременно для соотечественников - пути пробуждения и развития на основе высоких идеалов и ценностей. Во время пребывания на Западе Вивекананда обосновывает «презентационный» образ индуизма, в котором акцентированы все его позитивные стороны - представление о Боге (Брахмане), ведантистское тождество Бога и души человека, устремлённость к освобождению, разнообразие путей достижения Бога (карма, раджа, джняна и бхакти), гуманизм и т. д. Для индийской аудитории он выводит на первый план негативные стороны - слепую веру, авторитаризм брахманства, ограничения кастовой системы, гендерное неравенство, - всё, что скрывает высочайшие истины индуизма от самих его адептов и препятствует пробуждению Индии. Индуизм у Вивекананды - это религия, которая учит о божественной сути человека и ведёт к свободе. Цель индуизма - достижение и лицезрение единого Бога, и весь комплекс вер, символов и практик - это лишь средства постижения высшей реальности и истин, своеобразное «духовное детство». «Идолопоклонство в Индии - это вовсе не нечто ужасное и отвратительное. Это никоим образом не источник пороков. Напротив, это стремление неразвитых умов постичь высшие ценности» [20, II, 18]. Потому индуизм учитывает потребности простых людей в мифе, символе и культах, прежде чем они «дорастут» до философии веданты, где заключена суть этой религии.
Индуизм, как и другие мировые религии это «религия книги» - Вед, давших откровение об устремлённости души к Богу. И именно религия Вед, отождествлённая с индуизмом, у Вивекананды оказалась способной объединять и ассимилировать разные культы и секты, идеи и формы и от этого только усиливаться. И поскольку индуизм для Вивекананды - это бытие и становление, а не доктрины и догмы, он описывает его как гармоническое «единство в многообразии», хотя и не идеализирует его, считая главными проблемами сектантство и фанатизм. Уравнивание индуизма с мировыми религиями происходит в его этическом и социальном аспектах: этика строится вокруг идеи самоотречения и следования долгу на основе высших ценностей любви, милосердия, добра, правды, бескорыстия и ненасилия (ахимсы). Социальные аспекты индуизма в концепции Вивекананды выстроены вокруг этики, освящающей жизнь верующих, и потому любая деятельность может быть высоким служением Богу, и в первую очередь - социальное служение и борьба с социальными пороками, бедностью и невежеством. Сторонник религиозного универсализма в духе Рамакришны, Вивекананда представил индуизм в качестве одной из мировых религий, необыкновенно терпимой к любым формам проявления любви к Богу и носительницей непреходящих духовных истин, ценных для всего человечества.

В итоге у бенгальских интеллектуалов Бонкимчондро и Вивекананды, а позже у Бипинчондро Пала и Ауробиндо Гхоша, складывается образ индуизма как равного другим высшим религиям - обращение к каждому человеку независимо от любых характеристик и обстоятельств, обоснование Бога как Бога человеческого, носимого в сердце, порыв к свободе, спасению и избавлению от страдания. Оба мыслителя, рисуя национальный облик родной религии, акцентируют не только универсальность её этики, но и эстетическую её сторону, и именно благодаря сочетанию универсального смысла и национального колорита создают привлекательный облик индуизма.

На этом фоне неоиндуистская мысль в Махараштре развивается скорее в противоположном направлении - отступлении от универсализации в сторону усиления религиозно-националистической окраски образа индуизма и вытеснения диалога с другими религиями. Ведущим неоиндуистским мыслителем здесь 
был Бал Гангадхар Тилак (1856-1920) - выходец из брахманской семьи, политик и идеолог экстремистов в политическом движении. От изучения европейской философии и исследования санскритских священных текстов Тилак пришёл к созданию политизированного образа индуизма, который идеологически и практически должен был стать инструментом объединения «всех индийцев» и активизации антиколониальной борьбы. В отличие от Вивекананды, Тилак не испытал влияния традиционных неортодоксальных вероучителей - хотя в Махараштре и был свой проповедник - Саи Баба из Ширди, развивавший своё учение на пересечении суфийской и адвайтистской традиций. Тилак действовал как политик-прагматик, и начав с просветительской работы, пришёл к критике реформаторов, связанных с Прартхана Самаджем. Глубокая озабоченность последних социальными реформами вызвала неприятие Тилака, - он выступал против отмены детских браков, помощи вдовам и их вторичного замужества, а также поддерживал движение в защиту коров, а защиту индуизма возводил в ранг религиозного долга. В трудах Тилака образ индуизма строится вокруг нескольких принципиально важных для него идей: древность откровения Вед, «Бхагавадгита» как текст, обосновывающий карма-йогу как путь действия и борьбы ради поддержания космического и социального порядка (дхармы), а также ориентация на моральные образцы-идеалы дживанмуктов и тесную связь дхармы и свараджа. А ядром образа индуизма по Тилаку становится хиндутва - «индусскость», качество, присущее всем: «Общий фактор в индийском обществе - это чувство Хиндутвы, - пишет он. - ... Мы говорим, что индусы Панджаба, Бенгалии, Махараштры, Телинганы и Дравиды едины, и причина тому - только Хиндудхарма» [Цит. по: 10, 247].

Признавая «всеобщую укоренённость» во всеобщей духовной основе - атмане, Тилак практически реабилитирует безо всяких оговорок ритуальную сторону индуизма, когда инициирует в 1895-1896 г. празднования в честь «общеиндийского» бога Ганеши и героя маратхов Шиваджи, чем придаёт религиозно-общинную окраску развёртывающемуся антиколониальному движению. В этом плане важно отметить, что к «экстремистскому» политическому движению примкнули не только вдохновенные молодые бенгальские политики Ауробиндо Гхош и Бипинчондро Пал, но и выходцы из «Арья Самаджа», которым импонировали неоиндуистские идеи Тилака и ставка на активное действие в политике. Сужение замысла и содержания индуизма до сугубо национально значимой религии - несмотря на подчёркивание её значения для человечества - привело к формированию и развитию религиозного экстремизма и индусского коммунализма в XX в., который активно использует идею хиндутвы для идеологического обоснования своих действий.

Итак, индуизм как универсальная религия - это творение, появившееся в ходе напряжённых духовных исканий индийской интеллигенции, некоторая - воспользуюсь термином П. А. Флоренского - «система символического описания» родной им религиозной традиции ради её оправдания - раскрытия истины о ней самой для самих себя, для соотечественников и для всего мира.

В результате интеллектуальной универсализации индуизма произошло выведение индийской духовной традиции на уровень «высших» (Тойнби) мировых религий - через сопоставление с ними и обоснование её высоких смыслов. Обоснование универсальности индуизма имело множество вариантов, сводимых к двум типам. Первый - негативная универсализация, идущая от критики формы и «буквы» религии к открытию высокого монотеистического духа и гуманистической этики как подлинного содержания индуизма. Этот тип характерен для религиозных реформаторов и обществ и строится на специфическом герменевтическом прочтении священных текстов, что определяет преимущественно элитарный характер соответствующих движений - при всём стремлении лидеров содействовать духовной трансформации всего народа. Второй тип - позитивная универсализация, приемлющая все виды форм богопочитания, но не исключающая и критики установлений, как воплощение высокого стремления каждого человека постичь божественный Абсолют. Этот тип больше ориентирован на широкие массы верующих, но вместе с тем, идя от герменевтики религиозных практик и повседневной жизни верующих, рискует вытеснением высоких истин на второй план и подменой их сиюминутными потребностями и интересами. Несмотря на различия, эти типы универсализации взаимно дополняют друг друга в создании образа индуизма как мировой религии, в которой объединились и сосуществуют разнообразные веры и культы, и которая является 
хранительницей высочайших истин, утраченных или забытых другими народами, исповедующими иные религии.

Появление самой идеи обращения в индуизм (как возвращения в его лоно у Дайянанды и др.) - ещё один признак универсализации, имевший следствием уже в $\mathrm{XX}$ в. появление неоиндуистских движений, открывающих возможность присоединиться к ним для всех желающих, включая иноверцев и иностранцев.

У этого образа-конструкта были и свои издержки: он способствовал формированию религиозного национализма и насыщению освободительного антиколониального движения религиозно-общинной проблематикой, а также он оказался весьма удобен для инструментального применения политикамикоммуналистами, заимствовавшими методы аргументации и риторики у неоиндуистских мыслителей. Однако тот же самый образ индуизма входит как органическая часть в позитивный образ современной Индии как страны, владеющей непреходящим духовным наследием и необыкновенно толерантной к другим народам и культурам.

\section{Библиография:}

1. Лысенко В. Г. Познание Чужого как способ самопознания: Запад, Индия, Россия (попытка ксенологии) // Вопросы философии. 2009. № 11. С. 61-77.

2. Рашковский Е. Б. Профессия - историограф. Материалы к истории российской мысли и культуры ХХ столетия. Новосибирск, 2001.

3. Роллан Р. Жизнь Рамакришны. Жизнь Вивекананды. Пер. с франц. М., 1991.

4. Рыбаков Р. Б. Буржуазная реформация индуизма. М., 1981.

5. Скороходова Т. Г. Понимание Другого в философии Бенгальского Возрождения // Вопросы философии. 2010. № 2. C. 141151.

6. Ткачёва А. А. «Новые религии» Востока. М., 1990.

7. Тойнби А. Дж. Постижение истории / Пер с англ. М.: Прогресс, 1991.

8. Штитенкрон Г. фон. О природе индуизма. О правильном употреблении обманчивого термина // Древо индуизма. М.: Восточная литература, 1999. С 246-264.

9. Bankim's Hinduism. An Anthology of Writing by Bankimchandra Chattopaddhyay. Ed. by. Amiya P. Sen. New Delhi, 2011.

10. Bose Nemai Sadhan. The Indian Awakening and Bengal. Calcutta, 1960.

11. Chatterjee Bankim Chandra. Sociological Essays: Utilitarianism and Positivism in Bengal / Transl. \& Ed. by S. N. Mukherjee, M. Maddern. Calcutta, 1986.

12. Duff Alexander. India and Indian Missions: Including Sketches of the Gigantic System of Hinduism both in Theory and Practice. Delhi, 1988.

13. Ghose Sankar. The Renaissance to Militant Nationalism in India. Bombay etc., 1969.

14. Halbfass W. India and Europe. An Essay of Philosophical Understanding. Albany, 1988.

15. Kopf D. Brahmo Samaj and Shaping of Modern Indian Mind. Princeton, 1979.

16. Orthodoxy, Heterodoxy, and Dissent in India. Ed by S. N. Eisenstadt etc. Berlin, etc.:, 1984.

17. Roy Raja Rammohun. The English Works. Ed. by J. C. Ghose. In 4 vols. New Delhi, 1982.

18. Sastri Sivanath. The History of the Brahmo Samaj. 2 vols. Calcutta, 1912-1919.

19. Studies in the Bengal Renaissance / Ed. by A. Gupta. Calcutta, 1958.

20. Vivekananda Swami. Complete Works. Mayavati Memorial Edition. 12th ed. 9 vols. Mayavati - Almora, 19982002.

\section{References (transliterated):}

1. Lysenko V. G. Poznanie Chuzhogo kak sposob samopoznaniya: Zapad, Indiya, Rossiya (popytka ksenologii) // Voprosy filosofii. 2009. № 11. S. 61-77.

2. Rashkovskii E. B. Professiya - istoriograf. Materialy k istorii rossiiskoi mysli i kul'tury KhKh stoletiya. Novosibirsk, 2001.

3. Rollan R. Zhizn' Ramakrishny. Zhizn’ Vivekanandy. Per. s frants. M., 1991.

4. Rybakov R. B. Burzhuaznaya reformatsiya induizma. M., 1981. 


\section{Культура и искусство 2(26) • 2015}

5. Skorokhodova T. G. Ponimanie Drugogo v filosofii Bengal'skogo Vozrozhdeniya // Voprosy filosofii. 2010. № 2. S. 141151.

6. Tkacheva A. A. «Novye religii» Vostoka. M., 1990.

7. Toinbi A. Dzh. Postizhenie istorii / Per s angl. M.: Progress, 1991.

8. Shtitenkron G. fon. O prirode induizma. O pravil'nom upotreblenii obmanchivogo termina // Drevo induizma. M.: Vostochnaya literatura, 1999. S 246-264.

9. Bankim's Hinduism. An Anthology of Writing by Bankimchandra Chattopaddhyay. Ed. by. Amiya P. Sen. New Delhi, 2011.

10. Bose Nemai Sadhan. The Indian Awakening and Bengal. Calcutta, 1960.

11. Chatterjee Bankim Chandra. Sociological Essays: Utilitarianism and Positivism in Bengal / Transl. \& Ed. by S. N. Mukherjee, M. Maddern. Calcutta, 1986.

12. Duff Alexander. India and Indian Missions: Including Sketches of the Gigantic System of Hinduism both in Theory and Practice. Delhi, 1988.

13. Ghose Sankar. The Renaissance to Militant Nationalism in India. Bombay etc., 1969.

14. Halbfass W. India and Europe. An Essay of Philosophical Understanding. Albany, 1988.

15. Kopf D. Brahmo Samaj and Shaping of Modern Indian Mind. Princeton, 1979.

16. Orthodoxy, Heterodoxy, and Dissent in India. Ed by S. N. Eisenstadt etc. Berlin, etc.:, 1984.

17. Roy Raja Rammohun. The English Works. Ed. by J. C. Ghose. In 4 vols. New Delhi, 1982.

18. Sastri Sivanath. The History of the Brahmo Samaj. 2 vols. Calcutta, 1912-1919.

19. Studies in the Bengal Renaissance / Ed. by A. Gupta. Calcutta, 1958.

20. Vivekananda Swami. Complete Works. Mayavati Memorial Edition. 12th ed. 9 vols. Mayavati - Almora, 19982002. 